\title{
University of Washington Establishes Donald R. Matthews Fund
}

\author{
Margaret Levi, University of Washington
}

Donald R. Matthews retired in January 1995 from the University of Washington. He is best known for his pioneering study, U.S. Senators and Their World, published in 1960 by the University of North Carolina Press and in 1962 by Vintage Books, and currently republished by Norton. He is also the author of Negroes and the New Southern Politics (with James Prothro in 1966), Yeas and Neas (with James Stimson in 1975), and The Party's Choice (with William Keech in 1976). He is currently completing a manuscript on a comparative study of chief executives in Norway, Britain, and the United States since World War II.

In 1985-86, Don Matthews served as vice president of the American Political Science Association. He was the recipient of a Guggenheim Fellowship in 1980-81 and the Bloedel Chair at the University of Washington in 1987-88. He was elected to the American Academy of Sciences in 1970 and was a fellow at the Center for Advanced Study in the Behavioral Sciences in 1964-65.

Matthews received his $\mathrm{Ph} . \mathrm{D}$. from Princeton in 1953. He joined the faculty of the University of Washington in 1976 and served as chairperson from 1976-83. He has also been a member of the faculty at the University of Michigan (1973-75), University of North Carolina (1957-63), and Smith College (1951-57). He was a Senior Fellow at The Brookings Institution (1970-73), and he has held visiting appointments at the London School of Economics, University of East Anglia, University of Oslo, University of Bergen, and Columbia University.

To honor Matthews and recognize both his distinguished scholarly achievements and his invaluable service to the Department of Political Science at the University of Washington, his colleagues have established the Donald R. Matthews Fund. The purpose is to enhance the study of American politics within the department he chaired for nine years. The money will provide stipends for research by faculty and graduate students, offer additional fellowship support, and generally encourage and facilitate scholarship in American poli-

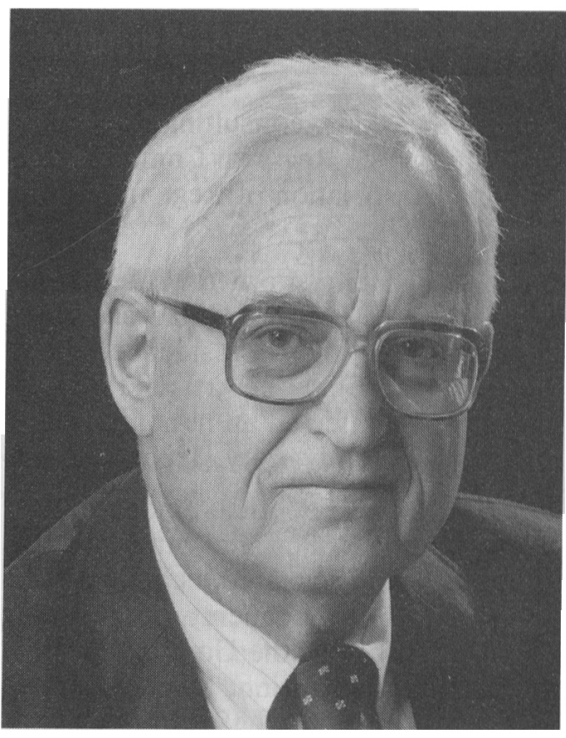

Donald R. Matthews

tics. Given that Matthews has increasingly become interested in the comparison of American political institutions and practices with those of other countries, potential projects may include a comparative dimension. Please mail your donation to Carole Davis-Mulligan, Department of Political Science, Box 353530, University of Washington, Seattle, WA 98195-3530. 